AWEJ for Translation \& Literary Studies, Volume 6, Number1. February 2022

DOI: http://dx.doi.org/10.24093/awejtls/vol6no1.6

\title{
The Role of Derivation in Teaching Quranic Vocabulary: Between Theory and Practice
}

\author{
Rabie Mohamed Hefny \\ Al-Iman Institute for Quranic Studies \\ Karabuk University, Karabuk, Turkey \\ Mohamed Fathy Mohamed Abdelgelil \\ Faculty of Islamic Contemporary Studies \\ Universiti Sultan Zainal Abidin, Terengganu, Malaysia \\ Corresponding Author: mfathy@unisza.edu.my
}

\section{Ammar Kamal Ibrahim Osman}

Faculty of Islamic Contemporary Studies

Universiti Sultan Zainal Abidin, Terengganu, Malaysia

Isyaku Hassan

Faculty of Languages and Communication

Universiti Sultan Zainal Abidin, Terengganu, Malaysia

Received:12/13/2021

Accepted: 1/26/2022

Published:2/24/2022

\begin{abstract}
Words with close meanings often cause difficulty in understanding the meanings of Quranic text. At times, Quranic words with similar meanings are even used in the wrong context. As such, understanding the morphological and semantic differences between Quranic words with close meanings becomes necessary. Therefore, this research aims to explore the roots and semantic differences of Quranic words with similar meanings and ascertain the role of derivation in teaching Quranic vocabulary. The research employed the descriptive-analytical approach to trace Quranic words with similar connotations and determine their derivation methods. The findings showed that the etymological origins of Quranic vocabulary with similar meanings can help greatly in clarifying the semantic features of the words. Similarly, the findings revealed that referring to the morphological structures of words helps to discover the meanings of Quranic words with similarity in linguistic origin and difference in structure. Therefore, derivation can be an effective means of determining the connotations of Quranic words, which can be useful in teaching Quranic vocabulary. This research could help instructors to advance the method of teaching Quranic vocabulary as well as the Arabic language in general. Nevertheless, the research is limited to the role of derivation in teaching Quranic vocabulary, and thus, further studies may focus on how the origin and formation of words can help students to develop language skills.
\end{abstract}

Keywords: Derivation, Quranic vocabulary, linguistic differences, teaching Arabic

Cite as: Hefny, R. M., Abdelgelil, M. F. M., Osman, A. K. I., \& Hassan, I. (2022). The Role of Derivation in Teaching Quranic Vocabulary: Between Theory and Practice . Arab World English 
AWEJ for Translation \& Literary Studies Volume, 6 Number 1. February 2022

The Role of Derivation in Teaching Quranic Vocabulary

Hefny, Abdelgelil, Osman, \& Hassan

Journal for Translation \& Literary Studies 6(1) 67-87.

DOI: http://dx.doi.org/10.24093/awejtls/vol6no1.6

\section{Introduction}

Vocabulary is the centerpiece of linguistic elements, preceded by sounds and followed by structures (Abdelgelil et al., 2021). Quranic vocabulary has great importance and specificity. As for its importance, Quranic vocabulary is present and common in many languages of non-Arab Muslims due to their involvement in Islamic culture (Essa, Hassan, Ramlee, 2020). The Noble Qur'an represents the main source of Islam, and therefore, Muslims often borrow words from the Arabic language as well as the Quranic vocabulary in particular, in addition to the influence of the Quranic language on Arab life since the advent of Islam.

The importance of Quranic words lies in the fact that a lot of Islamic rules as well as the understanding of legal rulings are based on their usage. Therefore, several earlier Islamic scholars paid particular attention to the significance of Quranic vocabulary (Al-Ișfahān̄i, 1999; Al-Farraa', n. d). Today, students of Arabic encounter certain challenges while trying to distinguish between Quranic words with close or more than one connotation (Ali, Brakhw, Nordin, \& ShaikIsmail, 2012; Aqila, \& Bijaksana, 2020). Nevertheless, ancient Arabic scholars realized the role of derivation in understanding linguistic differences between Quranic words (Abdelgelil, 2020). This research, therefore, seeks to explore the role of derivation in teaching Quranic vocabulary as an important source of Arabic. This research is expected to advance our knowledge of the major morphological and semantic features of Quranic words with close meanings.

\section{Literature Review}

\section{Relationship between Derivation and Teaching of Quranic Vocabulary}

In discovering an effective means of vocabulary development, derivation has been mentioned as an important feature of language that helps in this regard (Bertram, Laine, \& Virkkala, 2000; Gellert, Arnbak, Wischmann, \& Elbro, 2021). Therefore, what is the meaning of derivation? What is the relationship between derivation and the teaching of Quranic vocabulary? Derivation, which in Arabic means Ishtiqaq, is defined by Al-Jurjani (1983) as "deriving one word from another provided they match in meaning and structure, or differ in form" (p. 27). This definition, in particular, refers to the linguistic production skills and the transmission process which can be used in developing listening skills or the reception process. Arabic words and their meanings have comprehensive origins and roots with meanings and structures which have distinguished features while still retaining significant morphological and semantic measures.

To ascertain the correct meanings of Quranic words with close connotations, we return to the roots from which the words are derived. These roots inevitably demonstrate the semantic specificity of one word over another. Additionally, by identifying the morphological structure and meaning, semantic features of particular Quranic words with similar connotations can be ascertained. Thus, the derivation process of words helps individuals to understand the intended meaning of texts. According to Al-Razi (1980), "derivation is the most effective method of ascertaining the meanings of a word" (p. 1/29). Also, one of the characteristics of standard Arabic is that it is an etymological language. Thus, when we refer to the etymology of any word, its 
meaning becomes clear. Alternatively, only the derivation feature is needed to add an adjective to the lexical meaning of words, such as the following words: "الزبر" (Az-Zabur), "السفر" (As-Sifr), and "الكتاب" (Al-Kitab). Thus, how can a learner of Arabic or a researcher in Quranic studies determine the semantic features of Arabic words? Figure 1 represents the derivation method of the above-mentioned Arabic words.

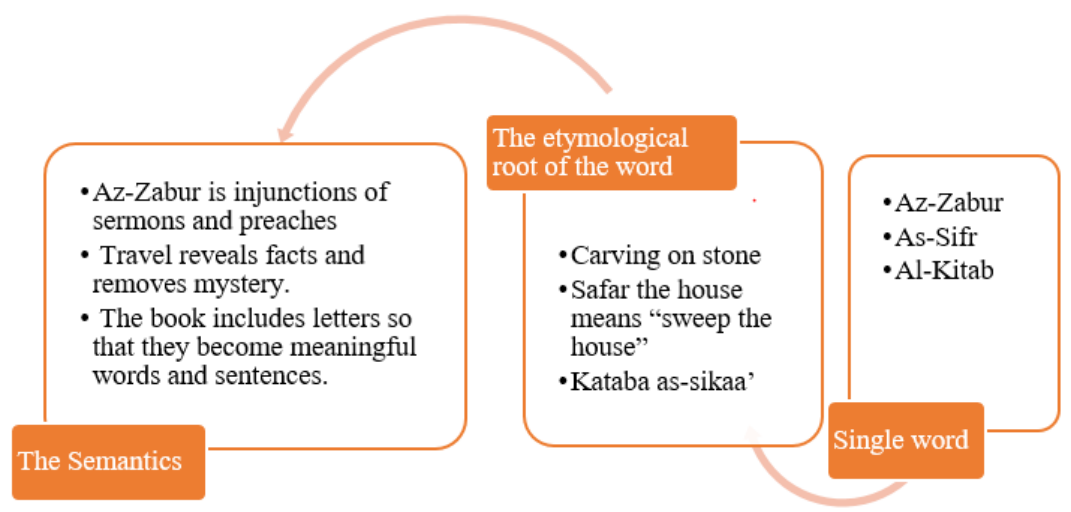

Figure 1: Derivation method of Quranic vocabulary

This is the derivation process from the etymological root of the words. For instance, the word "wrote", which is the past form of the verb "write" indicates that the action of writing happened and ended in the past. Also, the phrasal verb form "is writing", which shows that the action of "writing" is taking place at the moment, represents a continuous action. The Almighty Allah says:

So woe to those who scribe the Scripture with their own hands and then say, "This is from Allah," that they may purchase, in exchange for it, a small price. Woe to them on account of what their hands have written, and woe to them on account of what they earn (Surah alBaqarah: 79).

"كتب" The above verse contains nouns with verbs in the past and present tenses. When the word comes in the imperative form (write) preceded by the letter "w", its meaning becomes "will write" which indicates an action that will take place the future. The three formulas are found in the following verse.

And write for us good in this world and in the Hereafter. We turn to You in repentance. He said, "As for My punishment, I afflict with it whom I will. And My mercy extends to everything. So, I shall write it for those who fear, and pay Zakah, and those who do believe in Our verses. Those who follow the Messenger, the Ummi (unlettered) prophet whom they find written with them in the Torah and the Injil (The gospels), and who bids them the Fair and forbids the Unfair, and makes pure things permissible for them and makes in pure things pitted to them, and relieves them of their burden, and of the shackles that were upon them. So, those who believe in him and strengthen him, and help him and follow the light sent down with him, those are the ones who are successful (Surah al-A'raf: 156-157). 
The verb "write" comes at the beginning of the above verse, and subsequently, the verb comes in the future form "سأكتب" (will write). The word also appears twice in the following verse.

O you who believe, when you contract a debt among yourselves for a fixed period of time, write it down, and let the scribe write it between you with fairness. The scribe whom Allah has taught should not refuse to write, so let him write, and let the debtor dictate, but he should fear Allah his Lord, and not diminish anything out of it... (Surah al-Baqarah: 282).

The above method is similarly used to derive Quranic words with their various meanings. In practicing the teaching of Quranic vocabulary, students can be introduced to Quranic words in terms of meaning and usage as well as how words are derived. This process represents one of the most important aspects of language learning (Gellert et al., 2021). Understanding the intended meanings of words in the Quran requires the ability to identify the morphological and etymological forms of the words (Al-Askari, 2005; Al-Razi, 1980), and none of the previous studies have attempted to methodically investigate this phenomenon, particularly in teaching the Noble Quran. Therefore, this study aims to explore the role of derivation in teaching Quranic vocabulary to advance our understanding of how derivation helps in ascertaining the meanings of Quranic words with similar connotations.

\section{Analysis and Discussion}

\section{Derivation and its Role in Teaching Quranic Vocabulary}

The derivation of words, especially Quranic vocabulary, is very complex. Nevertheless, there is a continuous attempt in Islamic sciences, with their various subfields, to ease the understanding Quran from various viewpoints. This study focuses on two important aspects that could help us to understand the role of derivation in teaching Quranic vocabulary; 1) efforts made to explain the meanings of Quranic words; 2) the role of derivation in understanding the precise meanings of Quranic words with close meanings.

Efforts made by Islamic scholars to explain the meanings of Quranic words

Various explanations regarding Quranic lexicons have been documented by different scholars. For example, Al-'Askarî (2005), in his book entitled "Linguistic Differences" explained some crucial linguistic issues in "understanding parts of speech as well as their meanings and purpose" (p. 21). He stated the main motive of writing the book, saying:

I have never seen a kind of science and art of literature except that it has different books that bring its branches together and organize its types of speech concerning the difference between their close meanings. This closeness of meanings confuses learners. For this purpose, I wrote my book (Al-'Askarî, 2005, p. 21).

Therefore, Al-'Askarî was motivated to write his book by the desire to clear misperceptions in understanding word meanings. To achieve this goal, understanding the semantic features of a word is necessary for distinguishing the word from another. In the initial parts of the book, Al-'Askarî mentioned eight criteria for understanding linguistic differences. These criteria serve as the theoretical basis for linguistic differences. The writer succeeded in providing an effective method of understanding linguistic differences between words with similar meanings with derivation as one of the most crucial features. According to Al-'Askarî, an example of these criteria is the difference between "politics" (سياسة) and "management" (تدبير). This is because politics "سياسة" is 
derived from the word "السوس" (mites) which is a well-known animal. Politics refers to a course or principle of action adopted or proposed by a government, and as such, cannot be an attribute of God. The word "دبير" derived from "دبر" which means "last moment" or the end of something. Therefore, it is often said that "continuous management is a kind of policy" (Al-'Askarî, 2005, p. 17). In another context, the writer confirmed this difference, saying "a single management is not considered as a kind of policy, for every 'policy' is a 'management', and not every 'management' is a 'policy"' (p. 186).

Al-'Askarî identified the semantic features that distinguish between the two words "politics and management" through an etymological criterion that brings the words back to their original roots and accurately clarifies their semantic components. The scholar successfully applied this criterion based on historical semantic analysis, description, and comparison. Al-'Askarî selected the words of his book carefully, avoided the explanation of differences between strange words, and replaced them with Quranic words, as well as spoken language. He stated:

I have included enough evidence in my book without overestimation. I have also chosen my words based on what is mentioned in the Book of Allah, and according to the words of scholars and native speakers. Besides, I have not used strange words in my book (p. 21).

We must take into consideration that Al-'Askarî (may Allah have mercy on him) was referring to his era. The people of this era were closely related to more proficient Arabic speakers compared to us. Therefore, we are in dire need to facilitate the learning of Quranic vocabulary as ignorance about this field has prevailed in contemporary society.

Furthermore, Al-'Askarî has done justice to the choice of words in his book. Thus, the scholar took into account the learners' needs, on one hand, as well as the linguistic reality on the other hand. Until today, there has been an increased demand for the learning of the Arabic language for religious purposes (Essa et al., 2020). The language of the Quran has dominated Arab life to this day. A computer-based study of the Arabic language was conducted with huge lexicon data (Al-Zubaydī, 2001). The study revealed that the Arabic subject has about 11500 roots only. It was found that the Quran does not exceed $15 \%$ of the Arabic roots. The entire vocabulary of other documents does not deviate from the Quranic subject except by $2 \%$ only. This outcome means that the "dominant subject in Arabic writings and hadiths is the subject of the Quran" (Shaheen \& Musa, 1973, p. 246 as cited in Daoud, 2001).

This domination can also be found in the vocabulary of Muslims' languages which are borrowed from the Arabic language. Consider, for example, the Malay language, which is widely spoken in the South-East Asian Region (Indonesia, Malaysia, Brunei, Singapore, \& Southern Thailand). A study conducted by Bayoumi (2019) has proven that "the most commonly borrowed words in Malay are from the language of the Quran and Arabic. Hence, Quranic words are prevalent, especially in the Malay language" (p. 499).

The foregoing evidence supports the rationale for Al-'Askarî's choice of Quranic vocabulary in his book. It is, therefore, crucial for Muslims to incorporate Quranic vocabulary into the teaching Arabic for both native and non-native speakers, given that the Quranic text could help learners to achieve a high level of linguistic and vocabulary development (Tuaimah, 1998). 
Additionally, the Quranic text can be useful to the learners of Arabic by motivating them to learn the language. This is because religious motivation is still an important factor that determines learners' enthusiasm to learn Arabic.

Al-'Askarî emphasizes the role of the morphological structure in understanding the linguistic differences between words with similar meanings, stating that "if the formulas and the roots differ, the meanings will inevitably differ" (p. 13), such as the difference between "الاستفهام" (السؤال" (question). This is because the word "question" is only used for what the person is ignorant of or in doubt about. It may also be used in a situation where the questioner asks about what is known or not known to them. The interrogative form "استفل indicates the difference between "interrogation" and "question". Likewise, all nouns with different forms have different meanings (Al-'Askarî, 2005, p. 18).

Moreover, Al-'Askarî used the inflectional morphology to differentiate between the two verbs "الاستفهم" (interrogate) and "سأل" (question). As such, ascertaining semantic differences between Quranic words requires the knowledge of lexicon structure and derivatives. To clarify the precise intended meaning, there is a need for accurate knowledge of how lexicon structures are formed as well as the significance of each structure. Linguistic knowledge is crucial in clarifying these structures and their meanings.

The role of derivation in teaching Quranic vocabulary: A practical analysis

This analysis deals with Quranic vocabulary in two different aspects: 1) establishment of words origin etymologically; 2) establishment of words origin based on their morphological forms. First, to explain the etymological origin of Quranic vocabulary, this analysis focuses on words with close or similar meanings as represented in the following Table.

Table 1. Quranic words with similar meanings

\begin{tabular}{|c|c|c|c|c|c|c|}
\hline $\begin{array}{l}\text { Vocabulary } \\
\text { that denotes } \\
\text { knowledge }\end{array}$ & $\begin{array}{c}\text { Vocabulary } \\
\text { indicating the } \\
\text { covenant }\end{array}$ & $\begin{array}{l}\text { Vocabulary } \\
\text { related to } \\
\text { creations }\end{array}$ & $\begin{array}{l}\text { Vocabulary } \\
\text { related to } \\
\text { lying }\end{array}$ & $\begin{array}{l}\text { Vocabulary } \\
\text { related to } \\
\text { miserliness } \\
\text { and stinginess }\end{array}$ & $\begin{array}{c}\text { Vocabulary } \\
\text { related to } \\
\text { hatred }\end{array}$ & $\begin{array}{l}\text { Vocabulary } \\
\text { related to } \\
\text { discourse and } \\
\text { discussion }\end{array}$ \\
\hline "آنس" (Anasa) & $\begin{array}{c}\text { إصن'['iṣr] } \\
\text { means (treaty, } \\
\text { covenant, } \\
\text { contract) }\end{array}$ & $\begin{array}{c}\text { جَعلَ (ja'ala) } \\
\text { to create }\end{array}$ & (أفلَكَ & بَخِل (bakhila) & $\begin{array}{l}\text { شَ' (šana'a) to } \\
\text { hate intensely }\end{array}$ & $\begin{array}{c}\text { الحديث(hadith) } \\
\text { discourse }\end{array}$ \\
\hline 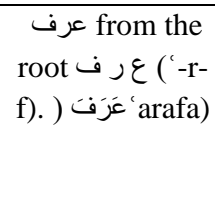 & $\begin{array}{l}\text { ('ahd) The } \\
\text { covenant or } \\
\text { the contact }\end{array}$ & خَلَقَ (khalaqa) & زُورر (zur) & $\begin{array}{c}\text { cُّ(šuḥ̣u) } \\
\text { scarcity and } \\
\text { niggardliness }\end{array}$ & مَقُتَ (maquta) & $\begin{array}{c}\text { القصصas) } \\
\text { (al-qașas) } \\
\text { means } \\
\text { 'stories' or } \\
\text { 'news' }\end{array}$ \\
\hline $\begin{array}{l}\text { (علم) ('alima), to } \\
\text { know, to have } \\
\text { knowledge, to } \\
\text { be cognizant, to } \\
\text { be aware }\end{array}$ & 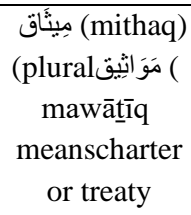 & $\begin{array}{c}\text { ف فُطر (fatara) } \\
\text { means: to rip } \\
\text { apart or break } \\
\text { apart or crack }\end{array}$ & & & & \\
\hline
\end{tabular}

Arab World English Journal for Translation \& Literary Studies

ISSN: 2550-1542 | www.awej-tls.org 
AWEJ for Translation \& Literary Studies Volume, 6 Number 1. February 2022

\begin{tabular}{|l|l|l|l|l|l|l|}
\hline $\begin{array}{l}\text { (tayaqqabic: } \\
\text { (taya) }\end{array}$ & & & & & & \\
\hline
\end{tabular}

As shown in Table 1, this study considers the etymological root of Quranic words with similar meanings. To analyze these words, four steps are considered: 1) mentioning some words with close meanings; 2) identifying the etymological root of the words; 3 ) clarifying the semantic differences between the words; 4) providing examples from Quranic verses, prophetic hadiths, and ancient Arabic poetry. For details regarding the analysis of the Quranic words presented in Table 1, please refer to Appendix A. The analysis shows that the etymological origins of Quranic vocabulary with similar meanings help greatly in clarifying semantic features of the words, which can be useful in teaching Quranic vocabulary. These findings are consistent with Al-Razi's (1980) assertion that "derivation" represents one of the most effective means of determining words' connotations. This is because Arabic is an etymological language, and the meaning of words becomes clear when we refer to their etymological origin.

Second, to clarify words origin based on their morphological structures, five steps were followed: 1) mentioning words with close meanings; 2) providing the morphological forms of the words; 3) clarifying the distinguishing features of the words; 4) giving examples from Quranic verses; 5) sorting out the words according to their morphological forms, taking into account the root system alphabetically. Please refer to Appendix B for practical analysis of Quranic words given their morphological structures. Similarly, this analysis revealed that referring to the morphological structures of words helps to discover the meanings of Quranic words with similarity in linguistic origin and difference in structure. This outcome supports Al-Askari's (2005) notion regarding the role of the morphological structure in understanding the linguistic differences between words with similar meanings. According to Al-Askari, when the origins of words differ, their meanings may also differ.

\section{Conclusion}

This study explored the etymological rooting of Quranic vocabulary and clarified the semantic differences between similar Qur'anic words. According to the findings, the etymological roots of Quranic words with close meaning play a role in clarifying their semantic features. Additionally, the reference to the semantics of morphological formulas revealed the meanings of Quranic words with similar linguistic roots. Besides, the etymological roots of the vocabulary or reference to the meanings of morphological formulas do not help to achieve the clarification of all differences between words with close meanings. Thus, it is preferable to rely on other structural, contextual, and semantic properties of Arabic to ensure comprehensiveness and determine the differences. Nevertheless, certain difficulties exist in the application of etymological rooting or reference to the meanings of morphological formulas, such as problems in determining the etymological root due to semantic change of words and failure to ascertain the root from which most Arabic words are derived, as well as the inadequacy of references, which leads to differing opinions on the etymological roots of many Arabic words. The findings of this study could be especially useful to educationists in developing the curriculum for teaching Quranic vocabulary as well as the Arabic language generally. However, the study is limited to the role of derivation in teaching Quranic vocabulary. Further research may focus on how the etymological and morphological roots of Quranic vocabulary can help students to develop language skills.

Arab World English Journal for Translation \& Literary Studies 
AWEJ for Translation \& Literary Studies Volume, 6 Number 1. February 2022

The Role of Derivation in Teaching Quranic Vocabulary

Hefny, Abdelgelil, Osman, \& Hassan

\section{About the Authors}

Dr. Rabie Mohamed Hefny is an Assistant Professor of Arabic sciences at Al-Iman Institute for Quranic Studies and Karabuk University, Turkey. He trains teachers of Arabic on how to teach the Arabic language to non-Arabic speakers. He has a keen interest in teaching Arabic as a second language. https://orcid.org/my-orcid?orcid=0000-0003-0432-7898

Dr. Mohamed Fathy Mohamed Abdelgelil is a Senior Lecturer in the Faculty of Islamic Contemporary Studies, Universiti Sultan Zainal Abidin (UniSZA), Malaysia. His areas of research interest include Quranic and language studies. https://orcid.org/0000-0003-3538-502X

Ammar Kamal Ibrahim Osman is a Master's degree researcher in the Faculty of Islamic Contemporary Studies, Universiti Sultan Zainal Abidin (UniSZA), Malaysia. His research focuses on Quranic studies, language, and management sciences. https://orcid.org/0000-0002-4967-284X

Dr. Isyaku Hassan is a Postdoctoral Researcher in the Faculty of Languages and Communication, Universiti Sultan Zainal Abidin (UniSZA), Malaysia. He is an active researcher with a keen interest in the areas of media linguistics, media and religion, cultural communication, interactive media, and language studies. https://orcid.org/0000-0002-8260-2894

\section{References}

Al-Quraan Al-Kareem.

Abdelgelil, M. F. M. (2020). Grammarians' critique of Quranic Qira'at. International Journal of Academic Research in Business and Social Sciences, 10(11), 1225-

1231.doi:10.6007/ijarbss/v10-i11/8199

Abdelgelil, M. F. M. et al. (2021). Arabic syntactic rules with reference to Quranic Qurra. International Journal of Academic Research in Business and Social Sciences, 11(7), 1707-1711. doi:10.6007/ijarbss/v11-i7/10463

Al-'Askarî, H, H. A. (2005). Al-furooq al-Laghawiyyah (Linguistic differences). By Muhammad Basil Ayoun As-swd. Beirut: Dar al-Kutob al-'Imiyyah.

Al-Farraa', Y. Z. (n. d). Ma'any al-Qur'an (Meanings of the Quran). By: Abdul fattah Ismail Shalaby and others. Cairo: Dar al-Masriyyah li-ta'leef wa at-Tarjamah.

Al-Ișfahānī, A. A. (1999). Al-Mufradat fi Gharib al-Quran (Vocabulary in the strange Quran). Beirut: Dar al-Ma'rifah

Al-Jurjani, A, M. (1983). At-Ta 'rifaat (Definitions). Beirut: Dar al-Kutob al-'Imiyyah.

Al-Razi, M. O. (1980). At-Tafsir al-Kabir wa Mafatih al-Ghayb (Great exegesis and keys to the unseen). Beirut: Dar Ihya Turats Beirut.

Al-Zubaydī, M. M. A. Ḥ. (2001). Tāj al-'Arūs min Jawāhir al-Qāmūs (The Bride's Crown from the Pearls of Dictionary). Beirut: Dār Maktabah al-Hayāt.

Ali, A., Brakhw, M. A., Nordin, M. Z. F. B., \& ShaikIsmail, S. F. (2012). Some linguistic difficulties in translating the Holy Quran from Arabic into English. International Journal of Social Science and Humanity, 2(6), 588-590.

Aqila, N., \& Bijaksana, M. A. (2020). Developing set of word senses of vocabulary in AlQur'an. Edumatic: Jurnal Pendidikan Informatika, 4(1), 83-90.doi: 10.29408/edumatic.v4i1.2119

Arab World English Journal for Translation \& Literary Studies 
AWEJ for Translation \& Literary Studies Volume, 6 Number 1. February 2022

Bertram, R., Laine, M., \& Virkkala, M. M. (2000). The role of derivational morphology in vocabulary acquisition: Get by with a little help from my morpheme friends. Scandinavian Journal of Psychology, 41(4), 287-296.doi:10.1111/1467-9450.00201

Bayoumi, N. (2019). Al-Mu 'jam al-mufahras li-alfaazal-Qur'an al-Karim (Pronunciation lexicon of the Noble Quran) used in the Malay Language: An introduction to constructing Arabic teaching texts for non-native speakers in Southeast Asia. Paper presented at the Third Conference on the Arabic Language in Southeast Asian Countries, Terengganu, Malaysia.

Dawood, M. (2001). Al- 'arabiyyah wa 'ilm al-lughah al-hadith (Arabic and linguistics in Hadith). Cairo: Dar Gharib Publishing.

Essa, M., Hassan, I., Ramlee, M. N. (2020). Developing language proficiency for academic purposes: A study of Sharia Law students in Malaysia. International Journal of Scientific and Technology Research, 9(03), 3043-3047.

Gellert, A. S., Arnbak, E., Wischmann, S., \& Elbro, C. (2021). Morphological intervention for students with limited vocabulary knowledge: Short-and long-term transfer effects. Reading Research Quarterly, 56(3), 583-601. doi: 10.1002/rrq.325

Shaheen, A, S., \& Musa, A. H. (1973). Dirasah Ihsaiyyah li-jizoor mu'jam Taj al-Arus min Jawahir al-Qamus (Statistical analysis of roots in the crown of the bride from the jewels dictionary). Kuwait: Kuwait University Press.

Tuaimah, R, A. (1998). Al-thqafah al-'arabiyyah al-islamiyyah bayna at-ta'leef wa at-Tadris (The Arabic language culture between writing and teaching). Cairo: Dar al-Fikr al-Arabi. 
AWEJ for Translation \& Literary Studies Volume, 6 Number 1. February 2022

\section{Appendices}

Appendix A: Etymological root of Quranic words with similar meanings

Table 2. Vocabulary that denotes knowledge

\begin{tabular}{|c|c|c|c|}
\hline Vocabulary & $\begin{array}{l}\text { The etymological } \\
\text { root }\end{array}$ & The Semantic & Evidence and Examples \\
\hline "آنس" (Anasa) & $\begin{array}{l}\text { Derived from } \\
\text { familiarity with the } \\
\text { appearance } \\
\text { something. }\end{array}$ & $\begin{array}{l}\text { The emergence of facts } \\
\text { and things and the } \\
\text { feeling of being familiar } \\
\text { with them }\end{array}$ & $\begin{array}{l}\text { Almighty Allah said: "and } \\
\text { then if you find them mature } \\
\text { of mind..." (An-Nisa: 6) } \\
\text { In the hadith; "when Ismael } \\
\text { came, he seemed to have felt } \\
\text { something unusual..." } \\
\text { (Bukhari, 2002, 4/143) } \\
\text { The poet said: "If a person } \\
\text { comes to you seeking } \\
\text { his lies... then look, } \\
\text { for looking for something is } \\
\text { not like certainty." (Ibn } \\
\text { Manzur, 1994, 6/16). The } \\
\text { teacher felt that his pupil has } \\
\text { a great superiority }\end{array}$ \\
\hline 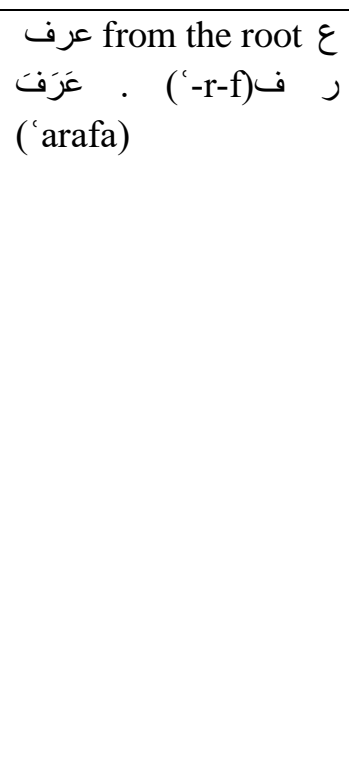 & $\begin{array}{l}\text { is derived from } \\
\text { cockscomb }\end{array}$ & $\begin{array}{c}\text { Distinguish the obvious } \\
\text { things in the slightest } \\
\text { knowledge }\end{array}$ & $\begin{array}{l}\text { "Those whom We have } \\
\text { vouchsafed the Book } \\
\text { recognize him even as they } \\
\text { recognize their children. Yet } \\
\text { those who have lost } \\
\text { themselves will not } \\
\text { believe." [Al-An'am: 20] } \\
\text { In the hadith "And if he saw } \\
\text { a thing which he disliked, } \\
\text { we would recognize that } \\
\text { (feeling) in his face. (al- } \\
\text { Bukhari 2002, 4/190). The } \\
\text { two students became } \\
\text { acquainted with one } \\
\text { another. }\end{array}$ \\
\hline $\begin{array}{l}\text { (علمَ ('alima), to } \\
\text { know, to have the } \\
\text { knowledge, to be }\end{array}$ & is derived from & $\begin{array}{l}\text { Awareness of the effects } \\
\text { of a thing and its } \\
\text { evidence }\end{array}$ & $\begin{array}{l}\text { Allah said (He said, } \\
\text { "Certainly, I know what you }\end{array}$ \\
\hline
\end{tabular}

Arab World English Journal for Translation \& Literary Studies 
AWEJ for Translation \& Literary Studies Volume, 6 Number 1. February 2022

The Role of Derivation in Teaching Quranic Vocabulary

Hefny, Abdelgelil, Osman, \& Hassan

\begin{tabular}{|c|c|c|c|}
\hline $\begin{array}{l}\text { cognizant, to be } \\
\text { aware }\end{array}$ & $\begin{array}{l}\text { The mark that } \\
\text { distinguishes } \\
\text { something }\end{array}$ & $\begin{array}{l}\text { and facts } \\
\text { in the correct manner. }\end{array}$ & $\begin{array}{l}\text { do not know.") [Al- } \\
\text { Baqarah: } 30] \\
\text { It was narrated that the } \\
\text { Prophet (Peace be upon } \\
\text { him) said: "O people, } \\
\text { knowledge only comes by } \\
\text { learning..) } \\
\text { (al-Bukhari, 2002, 25/1). } \\
\text { The teacher taught the } \\
\text { students the Arabic } \\
\text { language }\end{array}$ \\
\hline $\begin{array}{l}\text { Arabic: } \\
\text { (tayaqqana) }\end{array}$ & $\begin{array}{l}\text { is derived from } \\
\text { calmness and } \\
\text { purifying. }\end{array}$ & $\begin{array}{r}\text { calmness of oneself } \\
\text { and heart-warming } \\
\text { with what was learned }\end{array}$ & $\begin{array}{l}\text { and fAlmighty Allah said: } \\
\text { of the Hereafter they are } \\
\text { [al- Jcertain [in faith] } \\
\text { Baqarah:4] } \\
\text { Abu Tammam said: "They } \\
\text { have excelled over people } \\
\text { whose virtuous people } \\
\text { have unanimously } \\
\text { confirmed that they are the } \\
\text { best of people" (Abu } \\
\text { Tammam, 1994, p. 308). I } \\
\text { realized that the news is } \\
\text { true. }\end{array}$ \\
\hline
\end{tabular}

Table 3. Vocabulary indicating the covenant

\begin{tabular}{|c|c|c|c|}
\hline Vocabulary & $\begin{array}{l}\text { The etymological } \\
\text { root }\end{array}$ & The Semantic & Evidence and examples \\
\hline $\begin{array}{l}\text { (إصنّ]'ișr] means } \\
\text { (treaty, covenant, } \\
\text { contract) }\end{array}$ & $\begin{array}{l}\text { is derived from } \\
\text { ('așarrat) means, I } \\
\text { locked } \\
\text { a thing, I trapped it } \\
\text { and tightened it } \\
\text { tightly }\end{array}$ & $\begin{array}{l}\text { The covenant or treaty } \\
\text { whose reneging results } \\
\text { in its a great sin. }\end{array}$ & $\begin{array}{l}\text { Allah said: I } \text { He said, "Do } \\
\text { you affirm and accept my } \\
\text { covenant in this respect?" } \\
\text { They said, "We affirm. [Al } \\
\text { Imran: } 81 \text { ] } \\
\text { Ruba bin Al-Ajaj said: } \\
\text { "if you make the contract } \\
\text { like a covenant" (Al-Ajaj, D. } \\
\text { T, } 2 / 28 \text { ). The bonds of love } \\
\text { between brothers were } \\
\text { confirmed }\end{array}$ \\
\hline
\end{tabular}

Arab World English Journal for Translation \& Literary Studies

ISSN: 2550-1542 | www.awej-tls.org 
AWEJ for Translation \& Literary Studies Volume, 6 Number 1. February 2022

\begin{tabular}{|c|c|c|c|}
\hline $\begin{array}{l}\text { عf ('ahd) The } \\
\text { covenant or the } \\
\text { contact }\end{array}$ & $\begin{array}{l}\text { Derived from rain } \\
\text { sequence }\end{array}$ & $\begin{array}{l}\text { Recommending } \\
\text { something and } \\
\text { acknowledging }\end{array}$ & $\begin{array}{l}\text { Almighty Allah said: "Did I } \\
\text { not command you, O } \\
\text { children of Adam, not to } \\
\text { worship Satan, for he is } \\
\text { your sworn enemy" [Ya- } \\
\text { Sin: 60]. } \\
\text { It was narrated that Utba } \\
\text { bin Abi Waqqas authorized } \\
\text { his brother Sad bin Abi } \\
\text { Waqqas to take the son of } \\
\text { the slave-girl of Zama into } \\
\text { his custody..." } \\
\text { (al-Bukhari, 1994, 146/3) } \\
\text { Dhu'ayb Al-Hudhali said: } \\
\text { "If she doesn't find me, she } \\
\text { will say: did he betray the } \\
\text { covenant, or did the ally } \\
\text { commit a sin?" (Al- } \\
\text { Shanqeeti, 1965, 1/99). The } \\
\text { warriors (mujahidon) } \\
\text { promise each other to } \\
\text { achieve victory }\end{array}$ \\
\hline 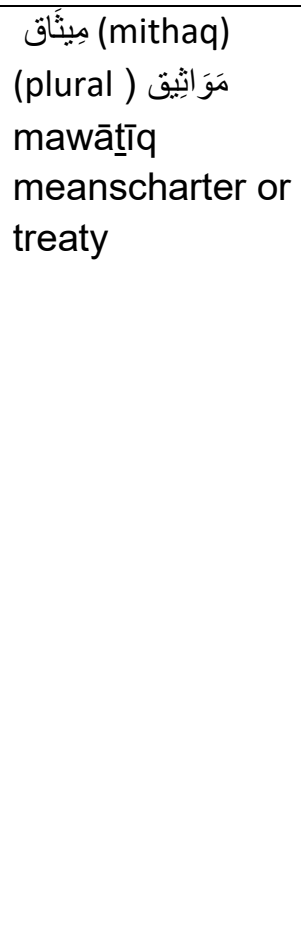 & $\begin{array}{l}\text { is derived from } \\
\text { tighten } \\
\text { the rope }\end{array}$ & $\begin{array}{l}\text { The covenant that was } \\
\text { judged by evidence }\end{array}$ & $\begin{array}{l}\text { Almighty Allah said: "Those } \\
\text { who break the covenant of } \\
\text { Allah after it has been } \\
\text { ratified, } \\
\text { sever bonds that Allah has } \\
\text { commanded to be } \\
\text { maintained, and spread } \\
\text { corruption in the land. It is } \\
\text { they who are the losers" } \\
\text { [Al-Baqarah: } 27 \text { ]. } \\
\qquad \text { Jamil Butahyna said: } \\
\text { And I said to her: "notice } \\
\text { that there is a charter and } \\
\text { covenants from God } \\
\text { between me and you" } \\
\text { (Mua'mmar, 1982, p. 39). }\end{array}$ \\
\hline
\end{tabular}

Arab World English Journal for Translation \& Literary Studies 
AWEJ for Translation \& Literary Studies Volume, 6 Number 1. February 2022

\begin{tabular}{|l|l|l|}
\hline & & $\begin{array}{l}\text { Did you register the } \\
\text { contracts in the Land } \\
\text { Registry Office? }\end{array}$ \\
\hline
\end{tabular}

Table 4. Vocabulary related to creations

\begin{tabular}{|c|c|c|c|}
\hline Vocabulary & $\begin{array}{l}\text { The etymological } \\
\text { root }\end{array}$ & The Semantic & Evidence and examples \\
\hline جَعَلَ (ja'ala) to create & $\begin{array}{l}\text { is derived from al- } \\
\text { ju'l: means wages. } \\
\text { It is what I have } \\
\text { given a person a } \\
\text { wage for the work } \\
\text { he does. }\end{array}$ & $\begin{array}{l}\text { Composing of something } \\
\text { from another something } \\
\text { already exists. }\end{array}$ & $\begin{array}{l}\text { The Almighty said: "Who } \\
\text { perfected everything He } \\
\text { created and initiated the } \\
\text { creation of man from clay. } \\
\text { Then He made his progeny } \\
\text { from the extract of a } \\
\text { worthless fluid" [Al-Sajdah: } \\
\text { 7-8] Al-A'sha said: "I said } \\
\text { poetry for you, O Salamah, } \\
\text { you are is the best one, and } \\
\text { you are worthy of that" (Al- } \\
\text { A'sha, d. t, p. 235). The } \\
\text { government made the road } \\
\text { clear }\end{array}$ \\
\hline خَلَقَ (khalaqa) & $\begin{array}{l}\text { (khalaqa) } \\
\text { create tanned skin } \\
\text { or leather i.e } \\
\text { measure it } \\
\text { according to what } \\
\text { he wants } \\
\text { before cutting }\end{array}$ & $\begin{array}{l}\text { creating anything } \\
\text { out of nowhere } \\
\text { according to a previous } \\
\text { estimate }\end{array}$ & $\begin{array}{l}\text { Allah says: "O mankind, } \\
\text { worship your Lord, Who } \\
\text { created you and those } \\
\text { before you, so that you may } \\
\text { become righteous" [Al- } \\
\text { Baqarah:21]. } \\
\text { Zuhair said: "what you have } \\
\text { estimated and designed, } \\
\text { you create it well, and } \\
\text { others estimate and design } \\
\text { but do not create because } \\
\text { of their inability" (Zuhair, } \\
\text { 1988, p. 29). }\end{array}$ \\
\hline $\begin{array}{l}\text { فَطَ (fatara) means: } \\
\text { to rip apart or break } \\
\text { apart or crack }\end{array}$ & $\begin{array}{l}\text { derived from "crack } \\
\text { the well" } \\
\text { i.e dig the well }\end{array}$ & $\begin{array}{r}\text { The beginning of } \\
\text { creation } \\
\text { with the installation }\end{array}$ & $\begin{array}{l}\text { Almighty Allah said: "All } \\
\text { praise belongs to Allah, the }\end{array}$ \\
\hline
\end{tabular}

Arab World English Journal for Translation \& Literary Studies 
AWEJ for Translation \& Literary Studies Volume, 6 Number 1. February 2022

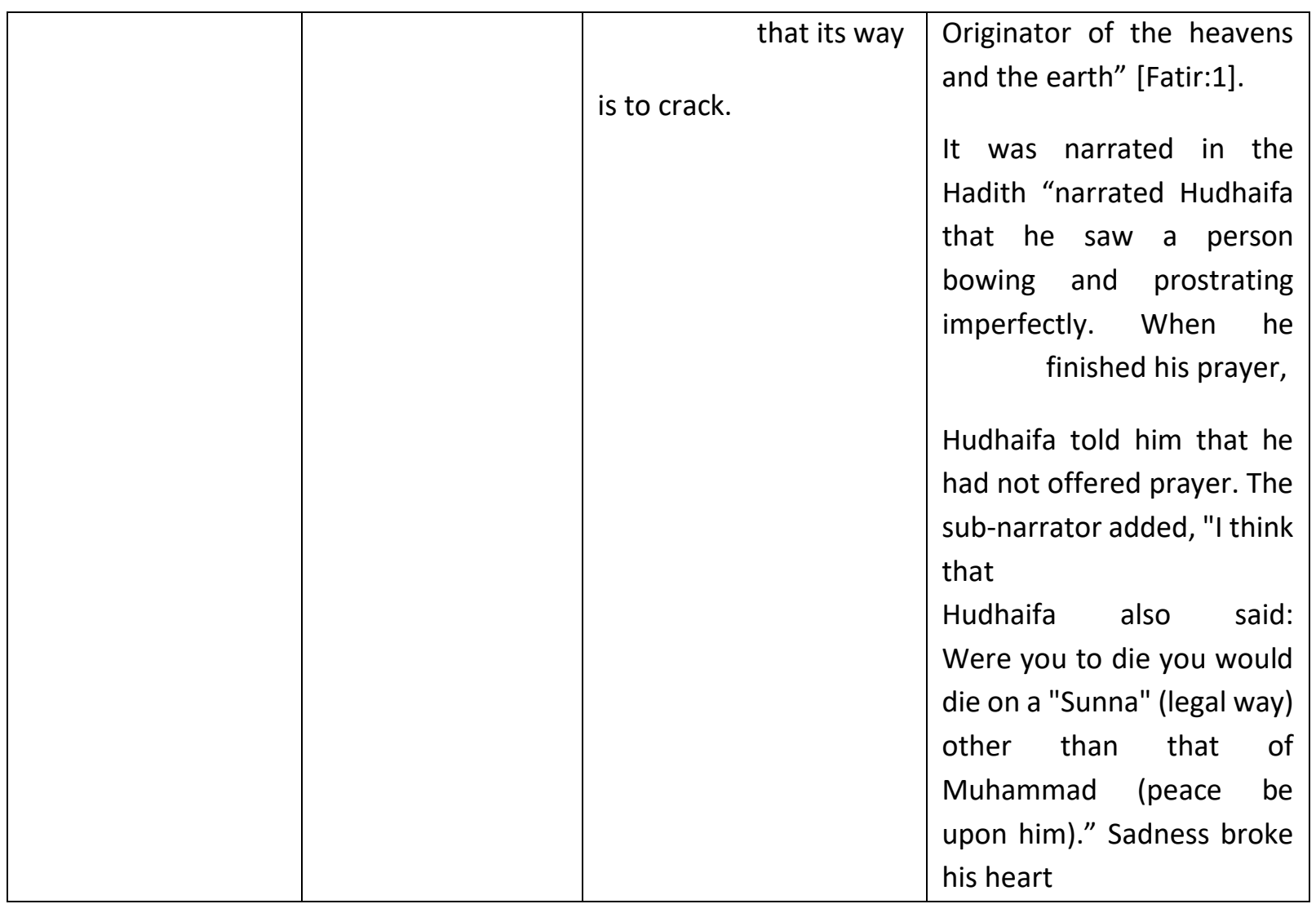

Table 5. Vocabulary related to lying

\begin{tabular}{|c|c|c|c|}
\hline 1. & & & \\
\hline Vocabulary & $\begin{array}{l}\text { The etymological } \\
\text { root }\end{array}$ & The Semantic & Evidence and examples \\
\hline أَفَكَ ('afaka) & $\begin{array}{l}\text { derived from the } \\
\text { earth destroyed, } \\
\text { i.e. burned from } \\
\text { the drought or } \\
\text { sterility }\end{array}$ & $\begin{array}{l}\text { exaggeration in lying } \\
\text { until the falsehood } \\
\text { becomes truth and truth } \\
\text { becomes falsehood }\end{array}$ & $\begin{array}{l}\text { Almighty Allah said: } \\
\text { "Beware! They are the ones } \\
\text { who, by way of a lie of } \\
\text { theirs, (have the audacity } \\
\text { to) say, "Allah has children" } \\
\text { - and they are absolute } \\
\text { liars. [Al-Saffat: } 151 \text { 152]. } \\
\text { Ruba bin Al-Ajaj said: "I } \\
\text { admire a man who is good } \\
\text { at lying and masters it, and } \\
\text { who mixes good speech } \\
\text { with bad one" (Al-Ajaj, D. T, } \\
\text { 1/408). "afaka: to divert }\end{array}$ \\
\hline
\end{tabular}

Arab World English Journal for Translation \& Literary Studies 
AWEJ for Translation \& Literary Studies Volume, 6 Number 1. February 2022

\begin{tabular}{|c|c|c|c|}
\hline & & & $\begin{array}{l}\text { someone away from } \\
\text { borrowing: to divert his } \\
\text { attention and made him } \\
\text { change his opinion by } \\
\text { deceit" (Omar, 2008, 2/103) }\end{array}$ \\
\hline زُور (zur) زُور & $\begin{array}{l}\text { is derived from } \\
\text { 'zawart something: } \\
\text { to enhance it and } \\
\text { improve it' }\end{array}$ & $\begin{array}{l}\text { Falsified a lie and } \\
\text { enhanced it outwardly, } \\
\text { so that it may be thought } \\
\text { to be true. }\end{array}$ & $\begin{array}{l}\text { Almighty Allah said: "So } \\
\text { refrain from the filth of the } \\
\text { idols and refrain from a } \\
\text { word of falsehood" [Al- } \\
\text { Hajj:30] } \\
\text { It was narrated in the } \\
\text { Hadith: The Prophet said } \\
\text { "And I warn you against } \\
\text { giving forged statement and } \\
\text { a false witness." } \\
\text { (al-Bukhari, 1994, 172/3). } \\
\text { The criminal forged the } \\
\text { money }\end{array}$ \\
\hline
\end{tabular}

Table 6. Vocabulary related to miserliness and stinginess

\begin{tabular}{|c|c|c|c|}
\hline Vocabulary & $\begin{array}{l}\text { The etymological } \\
\text { root }\end{array}$ & The Semantic & Evidence and examples \\
\hline بَخِلَ (bakhila) & $\begin{array}{lr}\text { is derived } & \text { from } \\
\text { withholding } & \text { and } \\
\text { constipation } & \end{array}$ & $\begin{array}{l}\text { withholding money and } \\
\text { belongings from those } \\
\text { who deserve it }\end{array}$ & $\begin{array}{l}\text { Almighty Allah said: "Yes, } \\
\text { you are such that you are } \\
\text { called upon to spend in } \\
\text { Allah's way, but some of } \\
\text { you withhold in miserliness } \\
\text { and he who withholds in } \\
\text { miserliness withholds } \\
\text { against himself and Allah is } \\
\text { the Need-Free, and you are } \\
\text { the needy. And if you turn } \\
\text { away, He will replace you by } \\
\text { some other people, then } \\
\text { they will not be like you" } \\
\text { [Muhammad: 38]. It was } \\
\text { narrated in the Hadith: The } \\
\text { Prophet (䱱) said, "The }\end{array}$ \\
\hline
\end{tabular}

Arab World English Journal for Translation \& Literary Studies 
AWEJ for Translation \& Literary Studies Volume, 6 Number 1. February 2022

\begin{tabular}{|c|c|c|c|}
\hline & & & $\begin{array}{l}\text { example of a miser and the } \\
\text { one who gives in charity, is } \\
\text { like the example of two } \\
\text { men wearing iron cloaks so } \\
\text { tightly that their arms are } \\
\text { raised forcibly towards their } \\
\text { collar-bones. So, whenever } \\
\text { a charitable person wants } \\
\text { to give in charity, his cloak } \\
\text { spreads over his body so } \\
\text { much so that it wipes out } \\
\text { his traces, but whenever } \\
\text { the miser wants to give in } \\
\text { charity, the rings (of the } \\
\text { iron cloak) come closer to } \\
\text { each other and press over } \\
\text { his body, and his hands get } \\
\text { connected to his } \\
\text { collarbones. Abu Huraira } \\
\text { heard the Prophet (axive } \\
\text { saying. "The miser then } \\
\text { tries to widen it but in vain." } \\
\text { (al-Bukhari } 1994 \text {, } 115 \text { ). } \\
\text { The miser withholds his } \\
\text { money for the poor }\end{array}$ \\
\hline $\begin{array}{l}\text { شُ (šuḥhu) scarcity } \\
\text { and niggardliness }\end{array}$ & $\begin{array}{l}\text { derived from the } \\
\text { sparse bone of the } \\
\text { shoulder (The part } \\
\text { of the arm from the } \\
\text { elbow to the wrist } \\
\text { or the fingertips" }\end{array}$ & $\begin{array}{l}\text { keen to prevent } \\
\text { goodness }\end{array}$ & $\begin{array}{l}\text { Almighty Allah said: "They } \\
\text { are niggardly towards you. } \\
\text { When danger comes, you } \\
\text { see them looking at you } \\
\text { with their eyes rolling like } \\
\text { someone in the throes of } \\
\text { death. But when danger is } \\
\text { over, they slash you with } \\
\text { sharp tongues, in greed for } \\
\text { gains. Such people have not } \\
\text { truly believed, so Allah will } \\
\text { render their deeds } \\
\text { worthless. That is easy for } \\
\text { Allah" (Al-Ahzab: } 19\end{array}$ \\
\hline
\end{tabular}

Arab World English Journal for Translation \& Literary Studies 
AWEJ for Translation \& Literary Studies Volume, 6 Number 1. February 2022

Table 7. Vocabulary related to hatred

\begin{tabular}{|c|c|c|c|}
\hline Vocabulary & $\begin{array}{l}\text { The etymological } \\
\text { root }\end{array}$ & The Semantic & Evidence and examples \\
\hline $\begin{array}{l}\text { شَ' (šana'a) to hate } \\
\text { intensely }\end{array}$ & $\begin{array}{l}\text { It is said that a man } \\
\text { has resentment and } \\
\text { resentment, i.e. } \\
\text { disgust }\end{array}$ & something & $\begin{array}{l}\text { Almighty Allah said: "O you } \\
\text { who believe, stand firm for } \\
\text { Allah by bearing true } \\
\text { testimony, and do not let } \\
\text { the hatred of a people lead } \\
\text { you away from justice. Be } \\
\text { just; that is closer to } \\
\text { righteousness. And fear } \\
\text { Allah, for Allah is All-Aware } \\
\text { of what you do" (Al- } \\
\text { Ma'idah: } 8 \text { ). It was narrated } \\
\text { in the Hadith: Hammad } \\
\text { said: "I heard Ayyub say: } \\
\text { Two kinds of people have } \\
\text { lied to al-Hasan: people } \\
\text { who believed in free will } \\
\text { and they intended that they } \\
\text { publicize their belief by it; } \\
\text { and people who had enmity } \\
\text { with and hostility (for al- } \\
\text { Hasan), saying: Did he not } \\
\text { say so and so? Did he not } \\
\text { say so and so?" (Abu } \\
\text { Tammam, 2009, 4/336). } \\
\text { "The rulers engaging in } \\
\text { fierce enmity and hostility } \\
\text { with each other and the } \\
\text { relations between their } \\
\text { peoples remain good." } \\
\text { (Omar, } 2008,2 / 1238 \text { ) }\end{array}$ \\
\hline مَقُتَ (maquta) & $\begin{array}{l}\text { derived from the } \\
\text { abhorrent one who } \\
\text { marries his father's } \\
\text { wife out of } \\
\text { resentment it an }\end{array}$ & & $\begin{array}{l}\text { Almighty Allah said: } \\
\text { "Indeed, those who } \\
\text { disbelieve will be } \\
\text { addressed, "The hatred of } \\
\text { Allah for you was [even] } \\
\text { greater than your hatred of }\end{array}$ \\
\hline
\end{tabular}

Arab World English Journal for Translation \& Literary Studies 
AWEJ for Translation \& Literary Studies Volume, 6 Number 1. February 2022

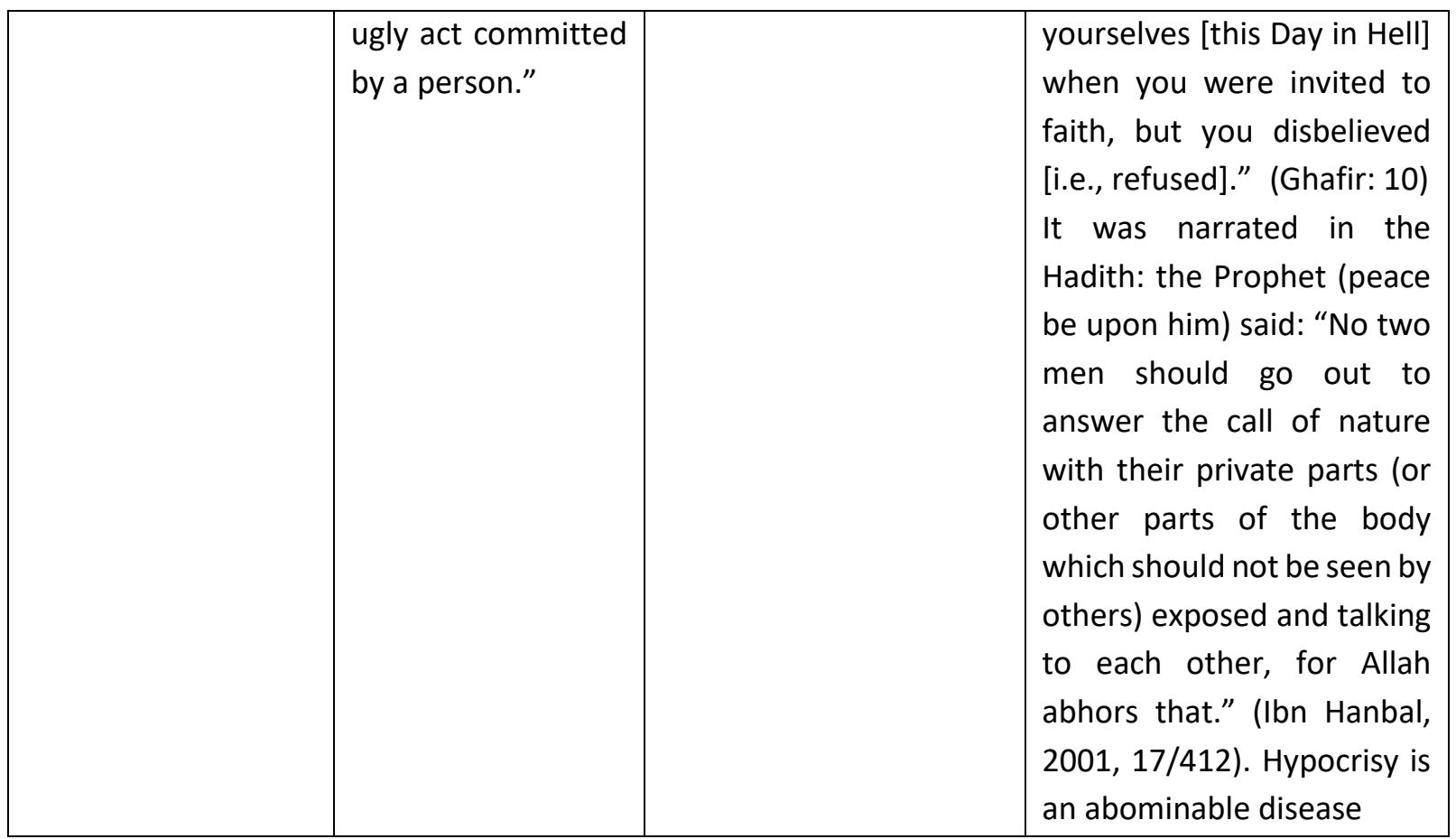

Table 8 . Vocabulary related to discourse and discussion

\begin{tabular}{|c|c|c|c|}
\hline \multicolumn{4}{|l|}{$2 . \quad:$} \\
\hline Vocabulary & $\begin{array}{c}\text { The etymological } \\
\text { root }\end{array}$ & The Semantic & Evidence and examples \\
\hline $\begin{array}{ll}\text { الحديث } & \text { (hadith) } \\
\text { discourse } & \end{array}$ & $\begin{array}{l}\text { derived from their } \\
\text { saying that the man } \\
\text { polished his sword: } \\
\text { So named because } \\
\text { no news is } \\
\text { presented to it }\end{array}$ & $\begin{array}{l}-\quad \text { A discourse } \\
\text { reveals new things. }\end{array}$ & $\begin{array}{l}\text { Allah said: "Allah has sent } \\
\text { down the best discourse, a } \\
\text { book containing subjects } \\
\text { resembling each other, } \\
\text { mentioned again and again, } \\
\text { shivered from which are the } \\
\text { skins of those who have } \\
\text { awe of their Lord. Then, } \\
\text { their skins and their hearts } \\
\text { become soft enough to } \\
\text { tend to the remembrance } \\
\text { of Allah." (Az-Zumar: 23). } \\
\text { Dhu'ayb Al-Hudhali said: "It } \\
\text { was talking - if you are } \\
\text { impressed by-is amazing" } \\
\text { (Omar, 2008, 2/1238; Al- } \\
\text { Shanqeeti, 1965, 1/92). }\end{array}$ \\
\hline
\end{tabular}

Arab World English Journal for Translation \& Literary Studies 
AWEJ for Translation \& Literary Studies Volume, 6 Number 1. February 2022

\begin{tabular}{|c|c|c|c|}
\hline & & & $\begin{array}{l}\text { Khaled is talking about } \\
\text { himself. This is a self-talk }\end{array}$ \\
\hline $\begin{array}{l}\text { (al-qașas) means } \\
\text { 'stories' or 'news' }\end{array}$ & $\begin{array}{l}\text { derived from their } \\
\text { saying: I tracked the } \\
\text { traces if I followed } \\
\text { it. The story is so- } \\
\text { called because it } \\
\text { follows each other } \\
\text { until it contains all } \\
\text { its facts. }\end{array}$ & $\begin{array}{l}\text { Long story } \\
\text { with successive issues }\end{array}$ & $\begin{array}{l}\text { Almighty Allah said: "We } \\
\text { relate to you rO Prophet" } \\
\text { the best of stories through } \\
\text { Our revelation of this } \\
\text { Quran, though before this } \\
\text { you were unaware rof } \\
\text { them" [Yusuf:3] } \\
\text { It was reported in Musnad } \\
\text { of Imam Ahmad about the } \\
\text { story of Musa and al-Khidr, } \\
\text { "Then he told him the news } \\
\text { of the boat" (Ibn Hanbal, } \\
2001,35 / 59 \text { ). Narrators tell } \\
\text { the audience exciting } \\
\text { stories }\end{array}$ \\
\hline
\end{tabular}

Appendix B: words origin based on their morphological forms

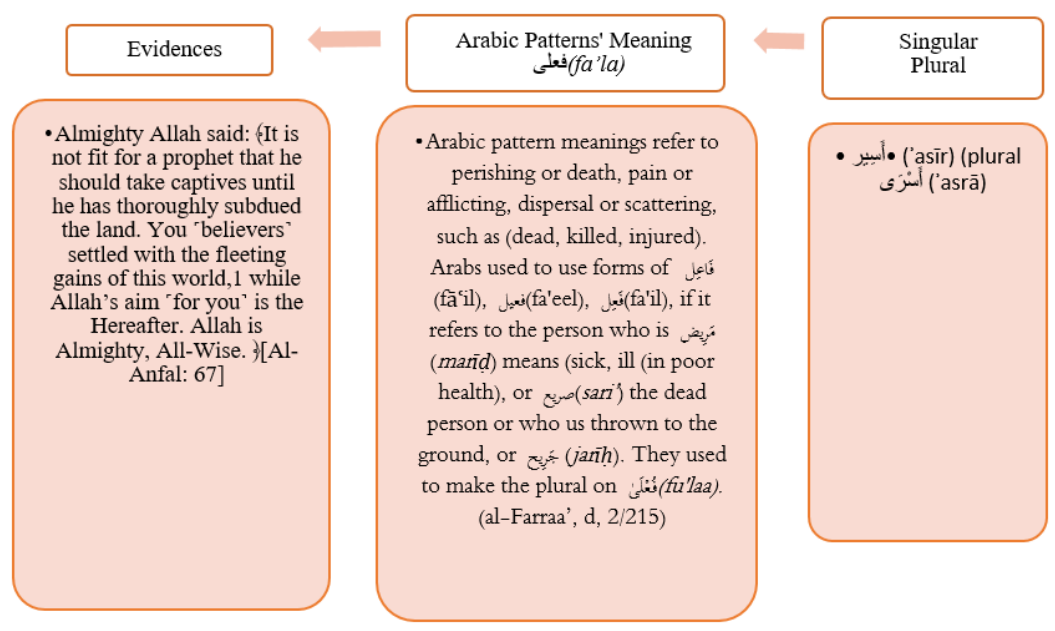

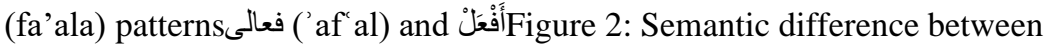

Arab World English Journal for Translation \& Literary Studies 
AWEJ for Translation \& Literary Studies Volume, 6 Number 1. February 2022
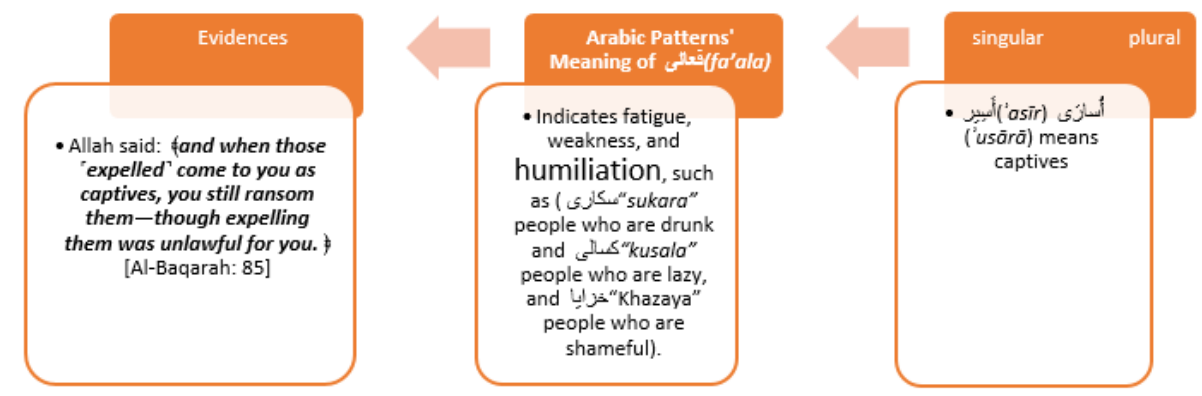

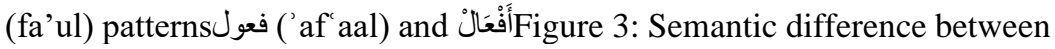

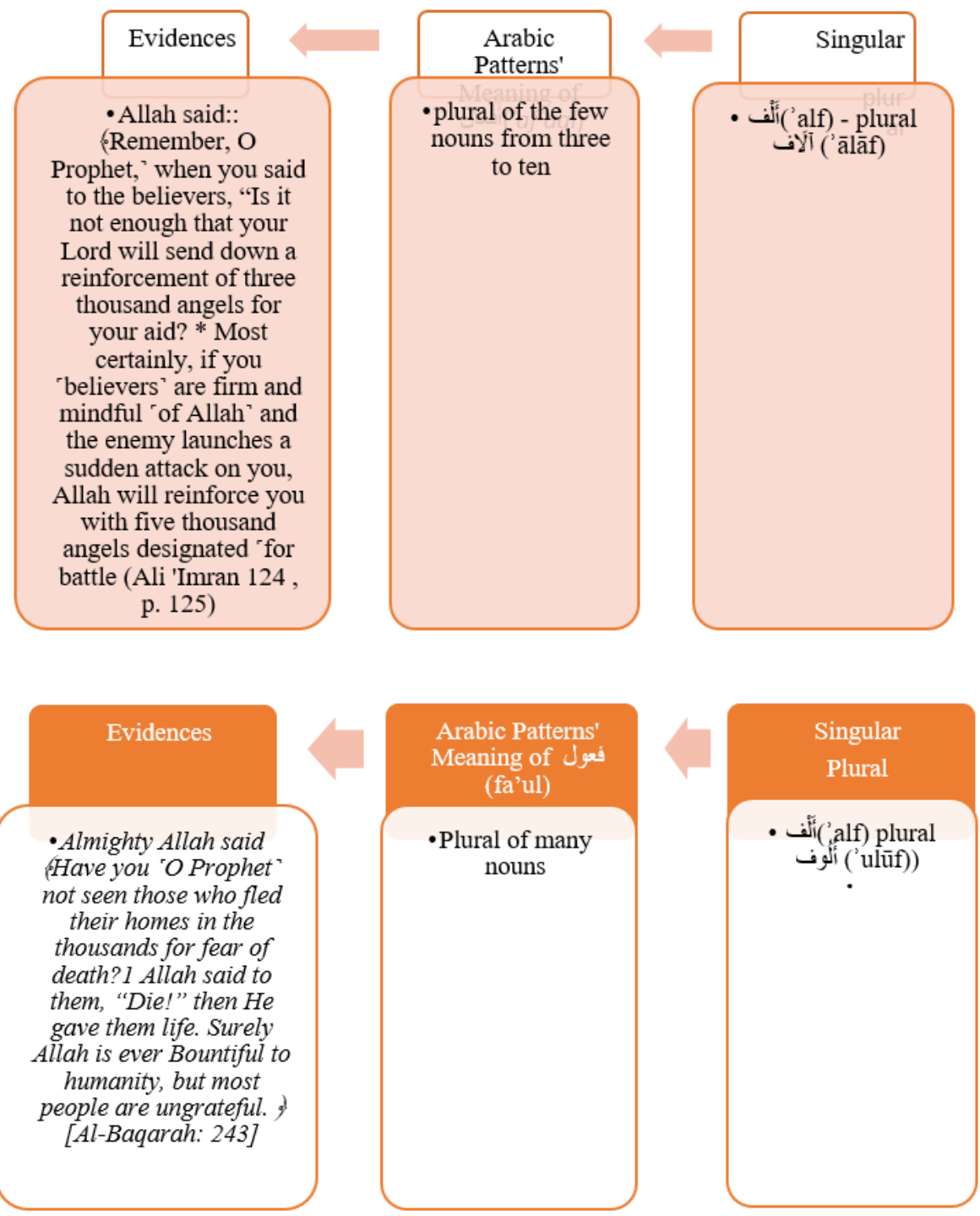

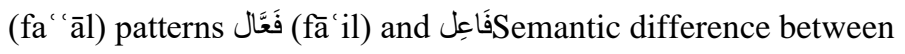

Arab World English Journal for Translation \& Literary Studies 
AWEJ for Translation \& Literary Studies Volume, 6 Number 1. February 2022

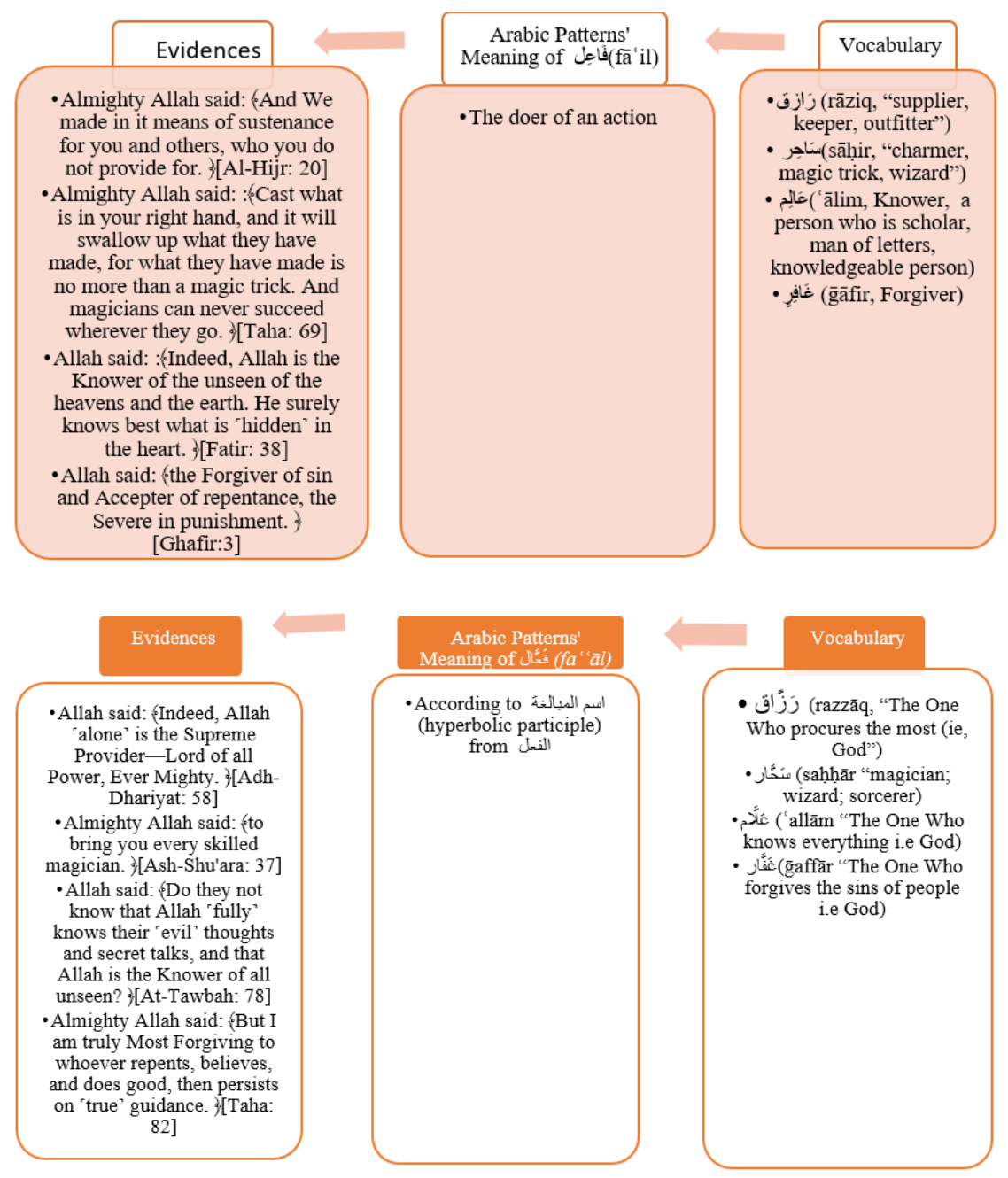

Arab World English Journal for Translation \& Literary Studies 